\title{
HUBUNGAN KONSTRUKSI, JENIS DAN JARAK WADAH SAMPAH DENGAN KEPADATAN LALAT PADA KANTIN SEKOLAH DASAR DI KECAMATAN WAY JEPARA KABUPATEN LAMPUNG TIMUR
}

\author{
Satria Tri Wibowo ${ }^{1)}$
}

\begin{abstract}
Abstrak
Kantin adalah tempat untuk siswa istirahat dan makan.Kantin juga dapat menghasilkan sampah menyebabkan adanya lalat. Lalat merupakan vektor dari berbagai macam penyakit saluran pencernaan seperti diare, typus, kholera, disentri dan lain sebagainya.Tujuan penelitian adalah untuk mengetahui hubungan pewadah sampah dengan tingkat kepadatan lalat di sekolah dasar Way Jepara Kabupaten Lampung Timur.

Jenis penelitian ini adalah analitik, dengan pendekatan cross sectional. Populasi pada penelitian ini adalah seluruh sekolah dasar Kecamatan Way Jepara yaitu berjumlah 30. Sampel diambil berdasarkan jumlah seluruh populasi yaitu berjumlah 30 . Instrumen yang digunakan adalah pengukuran kepadatan lalat serta kuisioner dan observasi. Analisis data dilakukan secara univariat dan bivariat (menggunakan uji Anova $\alpha=0,05$ ).

Hasil penelitian menunjukkan hubungan bermakna antara kepadatan lalat dengan konstruksi wadah sampah ( $p$-value $=0,006)$, jarak wadah sampah ( $p$-value 0,229$)$. Namun, tidak ada hubungan dengan jenis wadah sampah ( $p$-value $0,025<\alpha$, yang berarti ada hubungan bermakna antara terhadap kepadatan lalat. Saran yang telah diberikan kepada pemilik/ pengelola kantin, pihak sekolah dan instansi kesehatan, diharapkan dapat melengkapi sarana kantin dan memperbaiki sarana yang ada seperti peletakan wadah sampah, kepemilikan tutup wadah sampah dan untuk pihak instansi agar rutin mengendalikan vektor yang ada di sekitar tempat pewadahan seperti halnya pembuatan jebakan lalat sederhana dengan menggunakan botol plastik.
\end{abstract}

Kata Kunci : Wadah sampah, kepadatan lalat

${ }^{1)}$ Alumni Program Studi D4 Kesehatan Lingkungan Politeknik Kesehatan Tanjungkarang

\section{PENDAHULUAN}

Kantin adalah sebuah ruangan dalam sebuah gedung umum yang dapat digunakan pengunjungnya untuk makan, baik makanan yang dibawa sendiri maupun yang dibeli di sana. (Wikipedia, 2015). Karateristik kantin yang baik antara lain tersedia tempat cuci peralatan makanan dan minuman dengan air yang mengalir, tersedia tempat cuci tangan bagi pengunjung kantin/warung sekolah, tersedia tempat untuk menyimpan bahan makanan, tersedia tempat untuk menyimpan makanan jadi/siap saji yang tertutup, tersedia tempat untuk menyimpan peralatan makan dan minum, Lokasi kantin/warung sekolah minimal berjarak 20 meter dengan TPS Kepmenkes (RI No 1429 tahun 2006)

Kantin juga mempunyai dampak positif dan negatif. Dampak positif dari usaha kantin ialah memberikan pelayanan jasa pangan untuk pengunjung. Sedangkan dampak negatifnya dapat menghasilkan sampah. Hubungan sampah terhadap kesehatan secara garis besar dikelompokkan menjadi dua, yaitu hubungan langsung dan hubungan tidak langsung. Hubungan langsung terhadap kesehatan disebabkan adanya kontak langsung antara manusia dengan sampah. Sedangkan hubungan tidak langsung disebabkan adanya vektor yang membawa kuman penyakit yang berkembang biak didalam sampah kepada manusia (Hariza, 2011).

Lalat adalah hewan menjijikkan dan dapat berperan sebagai vektor pembawa penyakit. Ancaman lalat mulai diperhitungkan terutama setelah timbulnya masalah sampah yang merupakan dampak negatif dari pertambahan penduduk. Sampah yang tidak dikelola dengan baik akan mengundang lalat untuk datang dan kontak dengan manusia. Lalat senang hidup ditempat yang kotor dan peranan lalat dalam penularan penyakit pada umumnya bersifat 
mekanis yaitu lalat yang hinggap pada kotoran dan kotoran menempel pada kaki lalat dan hinggap pada makanan sehingga makanan tersebut terkontaminasi.

Dari survei awal tedapat 30 sekolah dasar yang ada di Kecamatan Way Jepara. Terdapat 12 sekolah dasar yang masih banyak dijumpai lalat yang berada di kantin sekolah terutama di sekitar pewadahan sampah. Hampir $60 \%$ kantin sekolah dasar tidak memenuhi persyaratan dalam pengolahan sampahnya, seperti wadah sampah yang rusak, tidak memiliki tutup, bocor, berbau, dan jarak wadah sampah sangat dekat dengan penyajian makanan. Kondisi ini akan mengundang lalat sehingga berisiko terhadap kesehatan siswa yang datang ke kantin sekolah. Penelitian bertujuan mengetahui hubungan konstruksi, jenis dan jarak wadah sampah dengan kepadatan lalat pada kantin sekolah dasar di Kecamatan Way Jepara, Kabupaten Lampung Timur

\section{METODE}

Penelitian menggunakan rancangan cross sectional (potong lintang), untuk mengetahui hubungan pewadahan sampah (konstruksi, jenis dan jarak) dengan kepadatan lalat di kantin Sekolah Dasar di Kecamatan Way Jepara Kabupaten Lampung Timur. Sampel penelitian ini berjumlah 30 kantin Sekolah Dasar yang berada di Kecamatan Way Jepara. Pengukuran dilakukan di area sekitar tempat wadah sampah diluar dan sekitar tempat wadah sampah yang dekat dengan penyimpanan makanan yang ada di seluruh kantin yang akan dihitung kepadatan lalatnya. Waktu Pengukuran dilakukan pada tanggal $15-23$ Mei yaitu pukul $(07.00-12.00$ WIB) berturut-turut dilakukan pengulangan tiga kali dalam satu hari dan dilanjutkan kembali pada tanggal $17-22$ Juli.

\section{HASIL}

\section{Kepadatan Lalat}

Penelitian dilakukan di 30 kantin sekolah dasar di Kecamatan Way Jepara. Setiap kantin sekolah dilakukan pengukuran selama 10 hari, pada dua titik pengukuran, yaitu di dalam dan di luar kantin. Pengukuran dilakukan pada tiga periode waktu, yaitu pagi hari $(08.00-8.30)$, pgi-siang (09.30-10.00), dan siang (11.0011.30). Pengukuran kepadatan lalat menggunakan Fly Grill, alat hitung lalat (Tele Counter), dan alat untuk menghitung waktu (Stop Watch).

Hasil penelitian mendapatkan bahwa kepadatan lalat tertinggi pada kantin SDN 1 Sumberejo, dan terendah di SDN 1 Labuhan Ratu Satu. Berdasarkan titik dan waktu pengukuran, kepadatan lalat di luar kantin pada pukul 08.00-08.30 sebanyak 14 ekor lalat, pukul 09.30-10.00 sebanyak 19 ekor, dan pukul 11.00-11.30 sebanyak 20 ekor. Sedangkan di dalam ruangan, pada pukul 08.00-08.30 sebanyak 9 ekor, pukul 09.30-10.00 sebanyak 11 ekor, dan pukul 11.00-11.30 sebanyak 10 ekor. Terdapat empat sekolah dengan kepadatan lalat lebih tinggi di dalam kantin dibandingkan di luar kantin, yaitu SDN 2 Labuhan Ratu Satu, SDN 4 Braja Sakti, SDN Sri Rejosari, dan SDN Braja Emas.

\section{Konstruksi Wadah Sampah}

Penilaian wadah sampah mengikuti SNI 192454-2002. Terdapat enam aspek kriteria konstruksi yang dinilai, yaitu tidak mudah bocor, kokoh atau kuat, mencegah berseraknya sampah, mempunyai tutup, mudah diangkat atau dipindahkan, dan cukup untuk menampung sampah sesuai kapasitas. Pada Tabel 1 terlihat bahwa konstruksi wadah sampah yang tidak mudah bocor sebanyak 21 buah $(70,0 \%)$ dan mudah bocor sebanyak 9 buah $(30,0 \%)$. Konstruksi wadah sampah yang kokoh atau kuat sebanyak 28 buah $(93,3 \%)$ dan yang tidak kokoh atau kuat 2 buah $(6,7 \%)$. Konstruksi wadah sampah yang mencegah berseraknya sampah sebanyak 26 buah $(86,7 \%)$ dan yang tidak mencegah berseraknya sampah sebanyak 4 buah $(13,3 \%)$. Konstruksi wadah sampah yang mempunyai tutup sebanyak $22(26,7 \%)$ dan yang tidak mempunyai tutup sebanyak 8 $(26,7 \%)$.

Konstruksi wadah sampah yang mudah diangkat dan dipindahkan sebanyak $26(73,3 \%)$, dan yang tidak mudah dipindahkan sebanyak 4 wadah $(13,3 \%)$. Konstruksi wadah sampah yang cukup untuk menampung sebanyak 21 $(70 \%)$, dan yang tidak sebanyak $9(30 \%)$. Berdasarkan hasil penilaian tersebut, maka konstruksi wadah sampah yang memenuhi syarat sebanyak $43,3 \%$, sedangkan yang tidak memenuhi syarat sebanyak $56,7 \%$. 
Tabel 1. Gambaran konstruksi wadah sampah pada kantin sekolah dasar

\begin{tabular}{lcccc}
\hline \multirow{2}{*}{ Keadaan Konstruksi } & \multicolumn{2}{c}{ Baik } & \multicolumn{2}{c}{ Tidak Baik } \\
\cline { 2 - 5 } Wadah Sampah & $\mathrm{n}$ & $\%$ & $\mathrm{n}$ & $\%$ \\
\hline Tidak Mudah Bocor & 21 & 70,0 & 9 & 30,0 \\
Kokoh atau Kuat & 28 & 93,3 & 2 & 6,7 \\
Mencegah Berseraknya Sampah & 26 & 86,7 & 4 & 13,3 \\
Mempunyai Tutup yang Mudah Dibuka dan Ditutup & 22 & 73,3 & 8 & 26,7 \\
Wadah Sampah Mudah di Angkat atau di Pindahkan & 26 & 86,7 & 4 & 13,3 \\
Cukup Untuk Menampung Sampah atau Sesuai Kapasitas & 21 & 70,0 & 9 & 30,0 \\
\hline
\end{tabular}

Tabel 2 menggambarkan rata-rata kepadatan lalat berdasarkan konstruksi wadah sampah dan peletakannya. Hasil penelitian mendapatkan bahwa rata-rata kepadatan lalat pada wadah sampah di dalam yang memenuhi syarat adalah sebanyak 4,15 $(\mathrm{SD}=703)$ ekor, dan tidak memenuhi syarat sebanyak $4,47 \quad(\mathrm{SD}=2,035)$ ekor. Hasil uji statistik tidak menunjukkan perbedaan kepadatan lalat berdasarkan kontruksi wadah sampah ( $\mathrm{p}$-value $=0,717)$.
Pada wadah sampah di luar ruangan, ratarata kepadatan lalat pada kontruksi wadah sampah yang memenuhi syarat sebanyak 5,46 $(\mathrm{SD}=2,46)$ ekor, dan yang tidak memenuhi syarat sebanyak 8,71 ( $\mathrm{SD}=3,236)$ ekor. Hasil analisis statistik menunjukkan perbedaan kepadatan lalat berdasarkan konstruksi ( $\mathrm{p}$ value $=0,006$ ).

Tabel 2. Kepadatan lalat berdasarkan kontruksi dan peletakan

\begin{tabular}{lccccc}
\hline \multicolumn{1}{c}{ Kontruksi } & Mean & SD & SE & P-value & $\mathrm{n}$ \\
\hline Wadah sampah di dalam & & & & & \\
$\quad$ Memenuhi syarat & 4,15 & 2,703 & 0,750 & 0,717 & 13 \\
$\quad$ Tidak memenuhi syarat & 4,47 & 2,035 & 0,493 & & 17 \\
Wadah sampah di luar & & & & & 13 \\
$\quad$ Memenuhi syarat & 5,46 & 2,504 & 0,694 & 0,006 & 17 \\
$\quad$ Tidak memenuhi syarat & 8,71 & 3,236 & 0,785 & & \\
\hline
\end{tabular}

\section{Jenis Wadah Sampah}

Observasi dilakukan di sekitar wadah sampah di luar kantin di seluruh sekolah dasar. Berdasarkan bahan, terdapat tiga jenis bahan wadah sampah, yaitu plastik $(70 \%)$, kayu/ anyaman bambu $(33,3 \%)$, dan konstruksi semen $(6,7 \%)$.

Rata-rata kepadatan lalat pada kontainer jenis plastik sebanyak $6,47(\mathrm{SD}=3,204)$ ekor, kontainer jenis kayu atau anyaman bambu sebanyak 8,09 ( $\mathrm{SD}=3,390)$ ekor, dan konstruksi semen sebanyak $10,00(\mathrm{SD}=2,828)$ ekor. Hasil ini menunjukkan bahwa lalat lebih suka berada pada kontainer dari bahan konstruksi semen. Namun hasil uji anova tidak menunjukkan perbedaan kepadatan lalat yang bermakna berdasarkan jenis bahan ( $\mathrm{p}$-value $=0,229)$.

\section{Jarak Wadah Sampah}

Penilaian jarak wadah sampah mengikuti Kepmenkes No. 1429 Tahun 2006 yaitu minimal 20 meter, dan jarak wadah sampah di dalam kantin minimal 2 meter dari makanan terbuka. Hasil pengamatan jarak wadah sampah di dalam kantin yang memenuhi persyaratan sebanyak $36,7 \%$, dan yang tidak memenuhi syarat sebanyak $63,3 \%$. Sedangkan jarak wadah sampah di luar kantin, sebanyak $76,7 \%$ memenuhi syarat, dan $23,3 \%$ tidak memenuhi.

Rata-rata kepadatan lalat di luar kantin yang memenuhi syarat adalah 5,55 $(\mathrm{SD}=3,174)$ ekor, dan di dalam kantin yang memenuhi syarat sebanyak 3,71 ( $\mathrm{SD}=1,113)$ ekor. Hasil analisis statistik menunjukkan perbedaan kepadatan lalat di luar ( $p$-value $=0,025$ ) berdasarkan persyaratan jarak, namun tidak menunjukkan perbedaan pada wadah di dalam kantin (pvalue $=0,218$ ). 


\section{PEMBAHASAN}

\section{Kepadatan Lalat}

Lalat merupakan hewan yang tinggalnya di tempat kotor seperti sampah. Sampah yang menumpuk secara komulatif dapat menjadi tempat perkembangbiakan lalat. Upaya untuk menurunkan populasi lalat sangat penting mengingat dampak yang ditimbulkan. Untuk itu, salah satu cara penilaian baik buruknya suatu lokasi dilihat dari angka kepadatan lalatnya. Dalam menentukan kepadatan lalat, pengukuran terhadap populasi lalat dewasa tepat dan bisa diandalkan daripada pengukuran populasi larva lalat. Tujuan dari pengukuran angka kepadatan lalat adalah untuk mengetahui tingkat kepadatan lalat, sumber tempat berkembangbiaknya dan jenis-jenis lalat. Menurut Depkes (1992), lokasi pengukuran kepadatan lalat adalah yang berdekatan dengan kehidupannya/kegiatan manusia karena berhubungan dengan kesehatan manusia, yaitu pemukiman penduduk yang menghasilkan timbulan sampah setiap harinya, tempat umum (pasar, rumah makan, hotel, dan sebagainya), dan lokasi sekitar TPS.

Untuk mengetahui angka kepadatan lalat disuatu wilayah dilakukan dengan cara mengukur angka kepadatan lalat. Pengukuran populasi lalat hendaknya dapat dilakukan pada setiap kali dilakukan pengendalian lalat (sebelum dan sesudah), serta memonitoring secara berkala, yang dilakukan sedikitnya 3 bulan sekali.

Lalat adalah binatang sebagai penular secara mekanik berbagai penyakit yang banyak kita jumpai termasuk dalam Ordo Diptera Sub Ordo Cyclorrhapha yang anggotanya terdiri lebih dari 116.000 spesies di seluruh dunia. Binatang ini berkembang biak pada habitat diluar hunian manusia yang telah membusuk, penuh dengan bakteri dan organisme lainnya, seperti vegetasi yang membusuk, kotoran hewan, sampah dan sejenisnya. Berbagai jenis famili yang penting antara lain Muscidae (berbagai jenis lalat rumah, lalat kandang, lalat tanduk), Calliphoridae (berbagai jenis lalat hijau ), dan Sarcophagidae (berbagai jenis lalat daging ). Struktur tubuh lalat umumnya berukuran kecii, sedang, sampai tergolong besar (Upik, 2006). Lalat betina pada umumnya telah dapat menghasilkan telur pada usia 4-8 hari, dengan 75 - 150 butir sekali bertelur. Semasa hidupnya, seekor lalat bertelur 5 - 6 kali.

Menurut Upik (2006), jenis-jenis lalat yang ada di Indonesia dibagi menjadi tujuh yaitu lalat rumah, lalat kandang, lalat hijau, lalat daging, lalat mimik, lalat (Musca sorbens), lalat rumah mungil. Namun di sekitar wadah sampah hanya terdapat sebagian jenis, salah satunya adalah lalat rumah. Lalat rumah (Musca domestika) termasuk kedalam famili muscidae, sebarannya di seluruh dunia. lalat ini berukuran sedang panjangnya 6-8 $\mathrm{mm}$, berwarna hitam keabuabuan dengan empat garis memanjang gelap pada bagian dorsal toraks. Matanya pada yang betina mempunyai celah yang lebih lebar pada lalat betina, sedangkan lalat jantan lebih sempit. Atenanya terdiri atas tiga ruas, ruas terakhir paling besar berbentuk silinder dan dilengkapi dengan arista yang memiliki bulu pada bagian atas dan bawah. Bagian mulut atau probosis lalat disesuaikan khusus dengan fungsinya yaitu untuk menyerap dan menjilat makanan berupa cairan atau sedikit lembek.

Dari hasil penilaian disimpulkan bahwa ratarata kepadatan lalat di seluruh sekolah dasar di Kecamatan Way Jepara sebanyak 11 ekor, di dalam kantin sebanyak 4 ekor dan di luar kantin sebanyak 7 ekor. Sekolah dasar yang memiliki rata-rata kepadatan lalat tertinggi adalah SDN 1 Sumberejo dan terendah SDN 1 Labuhan Ratu Satu. Hal ini disebabkan SDN 1 Sumberjo belum memiliki kantin pemanen, sehingga sampah yang masih berserakan.

Kepadatan lalat tertinggi pada titik pengukuran di luar pada pukul 11.00-11.30, yaitu sebanyak 20 ekor. Sedangkan di dalam kantin, tertinggi pada $09.30-10.00$, sebanyak 11 ekor. Hal tersebut terjadi karena di luar kantin sekolah volume sampah yang belum terangkut mencapai kapasitas masimal yaitu ketika siswa selesai aktifitas pukul (11.00-11.30). Sedangkan kepadatan lalat yang ada di dalam kantin tertinggi pada jam (09.30-10.00) disebabkan karena aktifitas siswa berada pada jam tersebut dan siswa memungkinkan menghasilkan sampah yang banyak kemudian menarik adanya vektor lalat untuk datang.

Berdasarkan hasil analisis, rata-rata kepadatan lalat lebih tinggi di dalam kantin dibandingkan di luar kantin pada 4 sekolah dasar yaitu SDN 2 Labuhan Ratu Satu, SDN 4 Braja Sakti, SDN Sri Rejosari, SDN Braja Emas, dikarenakan wadah sampah yang ada tidak sesuai kriteria yaitu tidak memiliki tutup dan tidak kedap air, hal tersebut kemungkinan juga kurangnya pengetahuan pemilik kantin yang ada pada sekolah tersebut. Sebaiknya untuk pihak sekolah segera menyediakan kantin sehat, dan mengganti wadah sampah yang 
memenuhi syarat yaitu kedap air dan mempunyai tutup. Perlu dilakukan pengendalian vektor yang ada di sekitar tempat wadah sampah dengan penangkapan lalat secara alami, yaitu dengan cara memasang perangkap lalat dengan botol plastik bekas.

\section{Keadaan Konstruksi Wadah Sampah}

Konstruksi wadah sampah adalah keadaan bentuk kondisi atau bangun wadah sampah secara keseluruhan yang ada di rumah makan, meliputi dinding wadah kuat, lantai tidak mudah bocor dan kedap air, mudah dipindahkan, mempunyai tutup yang mudah dibuka, volume cukup menampung sesuai kapasitas dan mencegah berserakannya sampah (SNI 19-2454-2002). Konstruksi wadah sampah pada pola pewadahan individual harus memiliki bentuk yang dipakai tergantung selera dan kemampuan pengadaanya dari pemiliknya dengan kriteria : a) Bentuk kotak, silinder, kantung atau container yang kuat, b) Mudah diangkat atau dipindahkan namun tidak mudah bocor, c) Ukuran dapat menampung 10-50 liter untuk pemukiman 100-500 liter untuk kantor, rumah makan atau toko besar dan hotel (Permenkes No.304 Tahun 1989).

Idealnya, konstruksi wadah sampah disesuaikan dengan jenis sampah yang akan dikelola agar mudah penanganannya seperti diatas. $\mathrm{Di}$ samping itu, dengan adanya konstruksi yang baik maka bau akibat pembusukan sampah yang juga menarik datangnya lalat, dapat diatasi. Air hujan yang berpotensi menambah kadar air di sampah, dapat dikendalikan serta percampuran sampah yang tidak sejenis dapat dihindari.

Konstruksi wadah sampah dapat berpengaruh pada sifat dan prilaku lalat yang menyukai tempat-tempat yang kotor dan bau. Menurut DITJEN PPM dan PLP 1992, ada beberapa angka recomendation control yaitu :

a. $\quad 0-2$ : tidak menjadi masalah (rendah)

b. 3-5: perlu dilakukan pengamatan terhadap tempat-tempat berkembang biakan lalat (sedang)

c. $6-20:$ populasi lalat dan perlu pengamatan lalat dan bila mungkin direncanakan tindakan pengendalian (tinggi)

d. $>21$ : populasi sangat padat dan perlu diadakan pengamanan terhadap tempat berkembangbiaknya lalat dan tindakan pengendalian (sangat tinggi)

Dari hasil Observasi yang dilakukan tentang keadaan konstruksi wadah sampah di sekitar tempat kantin sekolah dasar di Kecamatan Way Jepara dapat diketahui bahwa sebanyak 70\% wadah sampah tidak mudah bocor, 93,7\% konstruksi wadah sampah kokoh atau kuat, $86,7 \%$ konstruksi wadah sampah dapat mencegah berseraknya sampah, 73,3\% konstruksi wadah sampah yang mempunyai tutup, $86,7 \%$ konstruksi wadah sampah mudah diangkat atau dipindahkan, $70 \%$ konstruksi wadah sampah dapat menampung sesuai kapasitas. Menurut kriteria SNI 19-2454-2002 tentang tata cara teknis operasional sampah, konstruksi wadah sampah yang baik yaitu tidak mudah bocor, kokoh atau kuat, mencegah berseraknya sampah, mempunyai tutup, mudah dipindahkan dan cukup menampung sampah sesuai kapasitas. Dari Penjelasan tersebut, konstruksi wadah sampah pada kantin sekolah dasar sudah baik, Namun sebesar $(56,7 \%)$ wadah sampah tidak memenuhi syarat dikarenakan tidak terpenuhinya kriteria wadah sampah yang benar. Kebanyakan wadah sampah yang ada sekolah dasar Kecamatan Way Jepara tidak memiliki tutup sampah hal tersebut bisa menimbulkan bau tidak sedap dan dapat mengundang adanya lalat.

Adanya hubungan antara konstruksi wadah sampah diluar dengan kepadatan lalat dikarenakan terdapat jumlah sekolah dasar yang belum memiliki kantin sekolah, ada 13 sekolah dasar yang belum memiliki sarana kantin. Hal tersebut dapat diperjelas masih terdapat banyak wadah sampah yang secara konstruksi tidak memenuhi syarat seperti : tidak mempunyai tutup, tidak cukup menampung sampah sesuai kapasitas, dan terbuat permanen atau cor-coran hal yang jarang dibersihkan, hal tersebut dapat mengundang adanya vektor lalat yang datang pada tempat pewadahan sehingga bisa mengganggu kesehatan siswa.

\section{Jenis Wadah Sampah}

Jenis wadah sampah adalah bahan dasar pewadah sampah yang terbuat dari plastik, besi atau logam, tidak mudah rusak dan ekonomis. Alternatif jenis bahan wadah sampah harus bersifat kedap terhadap air, panas matahari, tahan diperiakukan kasar dan mudah dibersihkan. Jenis bahan wadah sampah hendaknya mendorong terjadinya upaya daurulang, yaitu disesuaikan dengan jenis sampah yang telah terpilah. Sebaiknya jenis bahan wadah sampah terbuat dari plastik, logam atau rangkaian besi yang ringan dan mudah dipindahkan namun tetap memenuhi syarat 
secara konstruksi sehingga dalam pengangkutan lebih memudahkan petugas kebersihan untuk mengangkut sampah dan ditempatkan sesuai dengan sistem pengangkutan sampahnya, mengingat jenis wadah sampah sebaiknya juga memenuhi persyaratan kuat dan tahan korosi dan tidak dapat dimasuki serangga dan binatang, serta terbuat dari bahan yang ekonomis dan mudah dapat. (Peraturan menteri PU No 304 Tahun 1989)

Kantin Sekolah Dasar di Kecamatan Way Jepara Kabupaten Lampung Timur memiliki sarana sanitasi berupa wadah sampah, dapat diketahui jumlah dan macam-macam jenis wadah sampah yaitu wadah sampah berbahan dasar plastik $(60 \%)$, wadah sampah jenis kayu/ anyaman bambu $(33,3 \%)$ dan jenis wadah bahan lain $(6,7 \%)$. Kriteria jenis wadah sampah yang diuraikan dalam SNI No 19-2454-2002 tentang tata cara teknik operasional pengelolaan sampah adalah tidak mudah rusak dan kedap air, ekonomis mudah dibuat dan mudah dikosongkan. Dari penjelasan tersebut, jenis wadah sampah pada kantin sekolah dasar sudah baik, terdapat $(70 \%)$ sudah memenuhi syarat karena kebanyakan jenis wadah sampah di kantin tiap sekolah dasar di Way Jepara adalah plastin yang kedap air.

Dapat dijelaskan rata-rata kepadatan lalat diluar kantin pada kontainer jenis plastik adalah 6,47 dengan standar deviasi 3,204 , dan kepadatan lalat maksimum 13, rata-rata pada kontainer jenis kayu 8,09 standar deviasi 3,390 dan kepadatan lalat 5, rata-rata kontainer dengan jenis bahan lainnya 10,00 standar deviasi 2,828. Dari hasil tersebut menunjukkan bahwa lalat lebih suka berada pada kontainer dengan jenis bahan lainnya seperti bahan corcoran yang permanen. Dan untuk rata-rata kepadatan lalat didalam kantin pada kontainer jenis plastik adalah 4,76 dengan standar deviasi 2,682 dan jumlah maksimal 10 lalat, kepadatan lalat pada kontainer jenis kayu 3,82 standar deviasi 1,662 dan jumlah maksimal 8 lalat, kontainer dengan jenis bahan lainnya 3,5 standar deviasi 2,121 dan jumlah maksimal 8 lalat. Dari hasil tersebut menunjukkan bahwa lalat lebih suka berada pada kontainer dengan jenis bahan plastik.

Dari hasil tersebut menunjukkan bahwa lalat lebih suka berada pada kontainer dengan jenis bahan lainnya seperti bahan cor-coran yang permanen. Hal tersebut disebabkan karena wadah sampah yang permanen lebih cenderung susah dibersihkan sehingga masyarakat khususnya pengelola kantin tidak memperdulikan sarana wadah sampah yang ada.

Hasil uji anova menyatakan $p$ value $0,229>$ $\alpha(0,05)$ dan $p$ value $0,513>\alpha(0,05)$ yang artinya tidak ada perbedaan yang bermakna antara kepadatan lalat diluar maupun didalam kantin pada jenis kontainer plastik, kayu dan jenis bahan lainnya, yang artinya tidak ada hubungan antara kepadatan lalat dengan jenis wadah sampah. Dimungkinkan karena wadah sampah yang berada di kantin sekolah dasar yang ada di Kecamatan Way Jepara kebanyakan berwadah plastik yang memenuhi syarat antara lain, kedap air, dan mudah dikosongkan. (SNI No 19-2454-2002). Penelitian ini sejalan dengan penelitian sebelumnya yang pernah dilakukan oleh Muhammad Tamyiz (2015) yang menyatakan bahwa tidak ada hubungan berarti antara jenis wadah sampah dengan kepadatan lalat.

\section{Jarak Wadah Sampah}

Menurut Kepmenkes No. 1429/Menkes/SK/XII/2006 tentang pedoman penyelenggaraan kesehatan lingkungan sekolah, jarak kantin minimal $20 \mathrm{~m}$ dari TPS sekolah. Keadaan kantin sekolah yang jaraknya $<20 \mathrm{~m}$ dari wadah sampah memungkinkan terjadi pencemaran terrhadap makanan yaang dijual dikantin, mengganggu penciuman karena menimbulkan bau dn penurunan nilai estetika serta memicu datangnya vektor seperti lalat karena tempat yang disenangi lalat adalah tempat basah, benda-benda organik, tinja sampah basah, kotoran binatang, tumbuhtumbuhan busuk, kotoran yang menumpuk secara komulatif. Lalat merupakan alat transportasi yang sangat baik dalam penularan penyakit.

Menurut Depkes (1992), Jarak terbang sangat tergantung pada adanya makanan yang tersedia rata-rata lalat terbang $6-9 \mathrm{Km}$, kadangkadang dapat mencapai 19-20 $\mathrm{km}$ dari tempat berkembangbiaknya. Umumnya daya terbang lalat tidak lebih dari 50 meter dari tempat perindukannya (Upik, 2006). Lalat dewasa sangat aktif sepanjang hari, dari makanan yang satu ke makanan yang lain. Lalat amat tertarik oleh makanan yang dimakan oleh manusia sehari - hari salah satunya adalah kue-kue basah yang mengandung gula dan susu yang sering dijual di pinggir-pinggiran pasar ataupun warung jajanan kantin hal tersebut karena lalat membutuhkan protein diperlukan untuk bertelur. Sehubungan dengan bentuk mulutnya, 
lalat hanya makan dalam bentuk cair atau makanan yang basah, sedangkan untuk makanan yang kering biasanya dibasahi terlebih dahulu oleh ludahnya baru dihisap.

Terdapat $(63,3 \%)$ jarak wadah sampah tidak memenuhi syarat yang ada di kantin sekolah dasar dikecamatan Way Jepara, karena kebanyakan sekolah dasar di Kecamatan Way Jepara belum memiliki sarana kantin sehingga banyak penjual luar yang berjualan disekitar sekolah dasar. Adanya hubungan antara jarak wadah sampah dengan kepadatan lalat dikarenakan terdapat jumlah perbandingan data yang signifikan antara jarak wadah keseluruhan yang memenuhi syarat yaitu $(63,3 \%)$ memiliki kepadatan lalat sedang dan $(36,4 \%)$ memiliki kepadatan lalat tinggi. Sedangkan jarak pewadah sampah yang tidak memenuhi persyaratan $(21,1 \%)$ memiliki kepadatan lalat sedang dan $(78,9 \%)$ memiliki kepadatan lalat tinggi. Jarak pewadah sampah pada kantin sekolah dasar di Kecamatan Way Jepara Kabupaten Lampung Timur ditemukan terdapat banyak pewadah sampah yang jaraknya tidak memenuhi syarat seperti halnya luas lahan yang tidak memadai untuk sarana kantin. Ratarata sekolah dasar yang ada di Kecamatan Way Jepara belum memiliki sarana kantin oleh sebab itu pemilik kantin rata-rata dari luar lingkungan sekolah sehingga jarak wadah sampah berdekatan dengan kantin itu sendiri.

Dari hasil analisis secara bivariat, kantin yang memenuhi syarat adalah 5,55 dengan standar deviasi 3,174, dan standar eror 0,957, maka dapat disimpulkan bahwa hasil $\mathrm{p}$ value $0,025<\alpha(0,05)$ artinya ada perbedaan yang bermakna antara kepadatan lalat diluar kantin pada jarak wadah sampah diluar kantin, yang artinya terdapat hubungan yang bermakna antara kepadatan lalat diluar dengan jarak wadah sampah diluar kantin (TPS).

Wadah sampah dalam kantin adalah wadah sampah yang berdekatan dengan makanan. Hal ini berisiko tinggi tercemarnya bibit penyakit yang disebabkan oleh lalat. Menurut Jurnal Studi Indonesia 2009, jarak wadah sampah yang baik minimal 2 meter dari tempat makanan namun dengan ketentuan wadah sampah kedap air dan memiliki tutup. Dapat dijelaskan rata-rata kepadatan lalat didalam kantin yang memenuhi syarat adalah 3,71 dengan standar deviasi 1,113 , dan standar eror 0,421 , maka dapat disimpulkan bahwa hasil $p$ value $0,218>\alpha(0,05)$ artinya tidak ada perbedaan yang bermakna antara kepadatan lalat didalam kantin pada jarak wadah sampah didalam kantin. Hal tersebut, dikarenakan hampir semua wadah sampah di kantin memiliki tutup dan kedap dengan air.

Sebaiknya pemilik kantin harus memperhatikan jarak wadah sampah yang berdekatan dengan makanan jajannya minimal 2 meter dan kondisi makanan harus tertutup. Dan pihak instansi pendidikan atau kesehatan perlu melakukan pengendalian vektor lalat seperti memasang perangkap lalat (fly trap), umpan kertas !engket berbentuk pita/lembaran (stinky tapes), dan melakukan sosialisasi rutin untuk menjelaskan pentingnya kesehetan lingkungan khususnya kantin.

\section{KESIMPULAN}

Rata-rata kepadatan lalat yang ada di kantin sekolah dasar Kecamatan Way Jepara berkategori tertinggi yaitu 11 lalat. Kondisi keadaan konstruksi wadah sampah pada kantin Sekolah Dasar di Kecamatan Way Jepara Kabupaten Lampung Timur 56,7 \% tidak memenuhi syarat. Ada hubungan bermakna antara konstruksi wadah sampah terhadap kepadatan lalat pada kantin. Kondisi jenis wadah sampah pada kantin Sekolah Dasar di Kecamatan Way Jepara Kabupaten Lampung Timur $70 \%$ memenuhi syarat. Tidak ada hubungan bermakna antara jenis wadah sampah terhadap kepadatan lalat pada kantin. Jarak lokasi wadah sampah pada kantin Sekolah Dasar di Kecamatan Way Jepara Kabupaten Lampung Timur $63,3 \%$ tidak memenuhi syarat. Ada hubungan bermakna antara jarak wadah sampah terhadap kepadatan lalat pada kantin.

\section{DAFTAR PUSTAKA}

Keputusan Menteri Kesehatan Republik Indonesia Nomor 1429/Menkes/SK/ VII/2006. Tentang Pedoman Penyelenggaraan Kesehatan Lingkungan Sekolah.

Hariza, Adnani., 2011. Ilmu Kesehatan Masyarakat, Nuha Medika. 137 halaman. Yogyakarta.

Buku Jurnal 2009. Jurnal Studi Indonesia volume 11-12, Universita Terbuka, Pusat Studi Indonesia.

Upik, Kesumawati Hadi., Sigit SH., 2006. Hama Permukiman Indonesia Pengenalan, Biologi dan Pengendalian. Fakultas Kedokteran Hewan Institut Pertanian 
Bogor ISBN: 979-25-6940-5, Bogor, 479 halaman.

Peraturan Menteri Pekerjaan Umum Republik Indonesia Nomor 03/Menkes/Per/1989 tentang Penyelenggaraan Prasarana dan Sarana Persampahan Dalam Penanganan Sampah Rumah Tangga dan Sampah Sejenis Sampah Rumah Tangga. Semarang.

Azwar, Azrul., 1995, Pengantar Kesehatan Lingkungan, Jakarta, Mutiara Sumber Widya.

Standar Nasional Indonesia, 2002. SNI 192454-2002, TentangTata Cara Tehnik Operasional Pengelolaan Sampah Perkotaan. Badan Standarisasi Nasional, Jakarta.
Departemen Kesehatan Republik Indonesia, 1992, Petunjuk Teknis tentang Pemberantasan Lalat, Direktorat Jenderal PPM dan PL, Jakarta. Tersedia http://www.pengertian_pakar.com/2015//se kolah-apa-itu-sekolah_7.html (13 April 2015; 12:30 WIB).

Peraturan Menteri Kesehatan Nomor 304/MENKES/PER/IV/1989 Tahun 1989, Tentang Persyaratan Kesehatan Rumah Makan Dan Restoran. Jakarta.

Tamyis, Muhammad., 2015. Hubungan Pewadahan Sampah Dengan Kepadatan Lalat Pada Rumah Makan Di Kelurahan Iring Mulyo Kecamatan Metro, Karya Tulis Ilmiah, Diploma III Jurusan Kesehatan Lingkungan Poltekkes Tanjung Karang, Lampung. 